\title{
Modulatory effect of $\alpha$-linolenic acid-rich garden cress (Lepidium sativum L.) seed oil on inflammatory mediators in adult albino rats
}

\author{
Bastihalli Tukaramrao Diwakar ${ }^{1}$, Belur Ramaswamy Lokesh ${ }^{2}$ and Kamatham Akhilender Naidu ${ }^{1 *}$ \\ ${ }^{1}$ Department of Biochemistry and Nutrition, Central Food Technological Research Institute, Council of Scientific and \\ Industrial Research, Mysore 570 020, India \\ ${ }^{2}$ Lipid Science and Traditional Foods, Central Food Technological Research Institute, Council of Scientific and Industrial \\ Research, Mysore 570 020, India \\ (Received 9 September 2010 - Revised 20 January 2011 - Accepted 21 January 2011 - First published online 27 April 2011)
}

\begin{abstract}
Vegetable oils containing $\alpha$-linolenic acid (ALA; $18: 3 n$-3) have been shown to modulate the functions of immunocompetent cells. The aim of the present study was to understand the modulatory effect of ALA-rich garden cress (Lepidium sativum L.) seed oil (GCO) on lipid composition, spleen lymphocyte (SL) proliferation and inflammatory mediator production by peritoneal macrophages (PM $\Phi$ ) in rats. Female Wistar rats were fed diets containing either GCO $(2 \cdot 5,5 \cdot 0$ and $10 \%, \mathrm{w} / \mathrm{w})$ or sunflower oil (SFO, $10 \% \mathrm{w} / \mathrm{w})$ for $8 \mathrm{weeks}$. Ex vivo proliferation of SL was measured by the 3-(4,5-dimethylthiazol-2-yl)-2,5-diphenyltetrazolium bromide assay. IL-2 and TNF- $\alpha$ in SL and PM $\Phi$ were analysed by ELISA. Inflammatory mediators such as NO, leukotriene $\mathrm{B}_{4}\left(\mathrm{LTB}_{4}\right)$ and $\mathrm{H}_{2} \mathrm{O}_{2}$ were measured in mitogen-activated PM $\Phi$. GCO significantly increased the levels of ALA, EPA and DHA, but reduced linoleic acid and arachidonic acid in SL and PMФ lipids. GCO (10\%) significantly decreased the concanavalin A (Con-A)- and phytohaemagglutinin-mediated proliferation of SL by 54 and $38 \%$, respectively, in comparison with SFO. A marginal decrease in IL-2 and TNF- $\alpha$ was observed in Con-A-stimulated SL and lipopolysaccharide-stimulated PMФ. $\mathrm{LTB}_{4}$ levels in Ca ionophore-stimulated PMФ were reduced by $40 \%$ in GCO-fed rats. NO release in response to various stimuli was significantly decreased in PM $\Phi$ of GCO-fed rats. The present study is the first report on the modulatory efficacy of GCO on immunomediators in rats. GCO modulated inflammatory mediators such as NO and $\mathrm{LTB}_{4}$, and thus may play a role in alleviating inflammatory conditions favourably.
\end{abstract}

Key words: Garden cress seed oil: Peritoneal macrophages: Spleen lymphocytes: Nitric oxide: Leukotriene Ba: TNF- $\alpha$

Fatty acids in membrane phospholipids determine the structural and physiological functions of the cell membrane ${ }^{(1)}$. Since dietary fats can modify the fatty acid composition of membrane phospholipids, they can perturb membranemediated functions of immunocompetent cells ${ }^{(2)}$. Long-chain (LC) PUFA serve as precursors for inflammatory lipid mediators. Arachidonic acid (AA; 20:4), an n-6 LCPUFA, gives rise to pro-inflammatory mediators, namely leukotriene $\mathrm{B}_{4}\left(\mathrm{LTB}_{4}\right)$ and $\mathrm{PGE}_{2}$, whereas EPA $(20: 5)$ and DHA, the $n$-3 LCPUFA, produce less inflammatory mediators such as leukotriene $\mathrm{B}_{5}$ and $\mathrm{PGE}_{3}$, resolvins and protectins ${ }^{(2,3)} \cdot n$-3 LCPUFA have been reported to alter the lipid composition of the T-cell membrane ${ }^{(4)}$ and the signalling of IL-2 receptors ${ }^{(5)}$. $n$-3 LCPUFA have also been reported to decrease the expression of genes involved in eicosanoid synthesis, scavenger receptor activity, adipogenesis, NF- $\mathrm{kB}$ and hypoxia signalling in human blood mononuclear cells ${ }^{(6)}$. Therefore, $n$-3 LCPUFA may have a therapeutic value in acute and chronic inflammation and also in disorders involving impaired immune function.

Mammals can convert $\alpha$-linolenic acid (ALA; 18:3n-3) to EPA and DHA; however, there are concerns regarding the efficiency of its conversion to $n-3 \operatorname{LCPUFA}^{(7,8)}$. It has been reported that a decrease in linoleic acid (LA; $18: 2 n-6)$ and an increase in ALA content in the diet can alter the levels of AA and EPA in the tissues of hamsters ${ }^{(9)}$ and rats $^{(10,11)}$. An ALA-rich diet has been reported to increase the levels of ALA and EPA in the phospholipid fraction of erythrocytes ${ }^{(12)}$, suppress the ex vivo proliferation of lymphocytes ${ }^{(13)}$ and inhibit TNF- $\alpha$ and IL-1 $\beta$ production in human mononuclear cells $^{(14)}$. ALA has been reported to modulate the T-helper 1/T-helper 2 balance when ingested at normal dietary concentrations ${ }^{(15)}$. These studies have demonstrated that the efficacy

Abbreviations: 5-LO, 5-lipoxygenase; AA, arachidonic acid; ALA, $\alpha$-linolenic acid; Con-A, concanavalin A; GCO, garden cress seed oil; LA, linoleic acid; LC, long chain; LPS, lipopolysaccharide; LTB $_{4}$, leukotriene $\mathrm{B}_{4}$; MTT, 3-(4,5-dimethylthiazol-2-yl)-2,5-diphenyltetrazolium bromide; PHA, phytohaemagglutinin; PMA, phorbol 12-myristate-13-acetate; PMФ, peritoneal macrophage; RPMI, Roswell Park Memorial Institute; SFO, sunflower oil; SL, spleen lymphocyte. 
of ALA to modulate the functions of immunocompetent cells may be of importance in altering the pathophysiological effects of inflammatory diseases.

Garden cress seed oil (GCO) is a good source of PUFA. It contains $32 \%$ of ALA and $12 \%$ of LA. GCO has a fairly balanced ratio of SFA:MUFA:PUFA (1:2.6:3) compared with flaxseed and perilla seed oil. GCO is a relatively stable oil due to the presence of a high concentration of natural antioxidants such as tocopherols $(1330 \mathrm{mg} / \mathrm{kg})$ and carotenoids $(5.32 \mathrm{mg} / \mathrm{kg})^{(16)}$. The major part of ALA in GCO is esterified at the sn-2 carbon of $\mathrm{TAG}^{(16)}$, hence it can be easily absorbed by the intestine. We have reported a significant increase in EPA and DHA levels in the serum, liver, heart and brain with a concomitant decrease in LA and AA in rats fed with a GCO diet ${ }^{(10)}$. The aim of the present study was to assess the modulatory effect of GCO on some key functions of immunocompetent cells such as proliferation and release of inflammatory mediators ex vivo.

\section{Materials and methods}

\section{Materials}

Garden cress seeds were purchased from a local market in Mysore. The seeds were identified and authenticated at the Department of Horticultural Sciences, University of Agriculture Sciences, Bangalore. Seeds were air-dried and flaked in a roller flaker (Kvarnmaskiner, Malmö, Sweden). Flaked garden cress seeds were pressed in a hydraulic press (B Sen Barry and Company, New Delhi, India), at a pressure of $98 \cdot 1$ $\mathrm{kPa}$ for $10 \mathrm{~min}$, to expel the oil. Oil was collected, flushed with $\mathrm{N}_{2}$ and stored at $-20^{\circ} \mathrm{C}^{(16)}$.

All chemicals used were of analytical grade. Fatty acid methyl ester standards, B trifluoride, 3-(4,5-dimethylthiazol2-yl)-2,5-diphenyltetrazolium bromide (MTT), dimethyl sulfoxide, Ca ionophore (A23187), concanavalin A (Con-A), phorbol 12-myristate-13-acetate (PMA), phytohaemagglutinin (PHA) and lipopolysaccharide (LPS) were procured from Sigma Chemical Company (St Louis, MO, USA). Roswell Park Memorial Institute (RPMI)-1640 medium and antibiotics were procured from Thermo Scientific Company (Rockford, IL, USA). Rat IL-2 ELISA kit was purchased from R\&D Systems, Inc. (Minneapolis, MN, USA). TNF- $\alpha$ was purchased from Koma Biotech (Seoul, South Korea).

\section{Animals and diets}

Weaned female Wistar rats (OUTB-Wistar, IND-cft (2c)) weighing 55-62 g, bred in the animal house facility at the Central Food Technological Research Institute, Mysore, India, were used in the present study. The experimental protocol adopted in the present study was approved by the Institute's animal ethical committee. Animals were housed individually in stainless-steel cages, in a room, where the temperature was maintained at $25 \pm 2{ }^{\circ} \mathrm{C}$. Animals were divided into four groups, with twelve animals in each group. They were fed with a semi-synthetic diet containing sunflower oil (SFO) 10 (SFO $10 \mathrm{~g} / 100 \mathrm{~g}$ ), GCO 2.5 (GCO $2.5 \mathrm{~g}+\mathrm{SFO} \quad 7.5 \mathrm{~g} / 100 \mathrm{~g}$ ),
GCO5 (GCO 5 g + SFO 5g/100g) and GCO10 (GCO 10g/100g), respectively. The composition of the isoenergetic, semisynthetic diet and its fatty acid profile are presented in Tables 1 and 2, respectively. Diets were prepared every week and stored at $4^{\circ} \mathrm{C}$. Animals were given a fresh diet ad libitum for 8 weeks. Animals had free access to their respective diets and water at all times throughout the study. After 8 weeks of feeding, rats were fasted overnight and were euthanised under diethyl ether anaesthesia. Blood was drawn by cardiac puncture, and serum was separated by centrifugation at $600 \mathrm{~g}$ for $10 \mathrm{~min}$ (after allowing the blood to clot at room temperature for $2 \mathrm{~h}$ ). Serum from animals of each group was pooled, heat inactivated at $54^{\circ} \mathrm{C}$ for $30 \mathrm{~min}$, filtered through a $0.2 \mu \mathrm{m}$ filter and used at a $2.5 \%$ level in culture media for primary cell culture experiments.

\section{Spleen lymphocyte preparation}

Spleens were aseptically removed, dilacerated and passed through a sterile cell strainer to form a cell suspension. The cell suspension was centrifuged for $10 \mathrm{~min}$ at $150 \mathrm{~g}$, and the resulting pellet was suspended in RPMI-1640 medium. Spleen lymphocyte (SL) were collected by centrifugation at $400 \mathrm{~g}$ for $30 \mathrm{~min}$ on Ficol Histopaq gradient, washed and re-suspended in complete media (RPMI-1640 containing 25 mm-HEPES supplemented with $2.5 \%$ autologous serum, penicillin $(60 \mathrm{mg} / \mathrm{l}))$, streptomycin $(100 \mathrm{mg} / \mathrm{l}), 2 \mathrm{~mm}-\mathrm{L}-$ glutamine and $10 \mu \mathrm{m}$-2-mercaptoethanol). The number of viable cells was counted by the trypan blue exclusion method using a haemocytometer, and cell number was adjusted to $1.5 \times 10^{6}$ cells/ml.

\section{Proliferation assay of rat spleen lymphocytes}

Proliferation of SL was evaluated by the MTT assay ${ }^{(17)}$. SL were cultured at a cell density of $1.5 \times 10^{5}$ cells/well in complete medium (RPMI-1640 containing $25 \mathrm{~mm}$-HEPES supplemented with $2.5 \%$ autologous serum, penicillin $(60 \mathrm{mg} / \mathrm{l})$, streptomycin

Table 1. Composition of the diets

\begin{tabular}{|c|c|c|c|c|}
\hline \multirow[b]{2}{*}{ Component $(\mathrm{g} / \mathrm{kg})$} & \multicolumn{4}{|c|}{ Diet } \\
\hline & SFO10 & GCO2.5 & GCO5 & GCO10 \\
\hline Casein & $200 \cdot 0$ & $200 \cdot 0$ & $200 \cdot 0$ & $200 \cdot 0$ \\
\hline Maize starch & $500 \cdot 0$ & $500 \cdot 0$ & $500 \cdot 0$ & $500 \cdot 0$ \\
\hline Sucrose & $100 \cdot 0$ & $100 \cdot 0$ & $100 \cdot 0$ & $100 \cdot 0$ \\
\hline Cellulose & $50 \cdot 0$ & $50 \cdot 0$ & $50 \cdot 0$ & $50 \cdot 0$ \\
\hline Mineral mix $^{*}$ & $35 \cdot 0$ & $35 \cdot 0$ & $35 \cdot 0$ & $35 \cdot 0$ \\
\hline Methionine & $2 \cdot 0$ & $2 \cdot 0$ & $2 \cdot 0$ & $2 \cdot 0$ \\
\hline Choline chloride & $3 \cdot 0$ & $3 \cdot 0$ & 3.0 & $3 \cdot 0$ \\
\hline Vitamin mix $\dagger$ & $10 \cdot 0$ & $10 \cdot 0$ & $10 \cdot 0$ & $10 \cdot 0$ \\
\hline SFO & $100 \cdot 0$ & $75 \cdot 0$ & $50 \cdot 0$ & 0.0 \\
\hline GCO & 0.0 & $25 \cdot 0$ & $50 \cdot 0$ & $100 \cdot 0$ \\
\hline
\end{tabular}

SFO10, sunflower oil (SFO) $10 \mathrm{~g} / 100 \mathrm{~g}$; GCO2.5, garden cress seed oil (GCO) $2.5 \mathrm{~g}+$ SFO $7.5 \mathrm{~g} / 100 \mathrm{~g}$; GCO5, GCO $5 \mathrm{~g}+$ SFO $5 \mathrm{~g} / 100 \mathrm{~g} ;$ GCO 10, GCO $10 \mathrm{~g} / 100 \mathrm{~g}$. * Bernhart Tommarelli salt mixture.

† AIN-76A containing per kg: $1.8 \mathrm{~g}$ vitamin $\mathrm{A}, 0.125 \mathrm{~g}$ vitamin $\mathrm{D}_{2}, 22 \mathrm{~g} \mathrm{DL}-\alpha$-tocopherol, $45 \mathrm{~g}$ ascorbic acid, $5 \mathrm{~g}$ inositol, $2.25 \mathrm{~g}$ menadione, $5 \mathrm{~g} p$-aminobenzoic acid, $4.25 \mathrm{~g}$ niacin, $1 \mathrm{~g}$ riboflavin, $1 \mathrm{~g}$ pyridoxine hydrochloride, $1 \mathrm{~g}$ thiamine hydrochloride, $3 \mathrm{~g}$ calcium pantothenate, $0.02 \mathrm{~g}$ biotin, $0.09 \mathrm{~g}$ folic acid, $0.00135 \mathrm{~g}$ vitamin $\mathrm{B}_{12}$ and $833.46 \mathrm{~g}$ sucrose carrier. 
Table 2. Fatty acid composition of the experimental diets*

(Mean values with their standard errors, $n 4$ )

\begin{tabular}{|c|c|c|c|c|c|c|c|c|}
\hline \multirow[b]{2}{*}{ Fatty acids (\% total fatty acids) } & \multicolumn{2}{|c|}{ SFO10 } & \multicolumn{2}{|c|}{ GCO2.5 } & \multicolumn{2}{|c|}{ GCO5 } & \multicolumn{2}{|c|}{ GCO10 } \\
\hline & Mean & SEM & Mean & SEM & Mean & SEM & Mean & SEM \\
\hline \multicolumn{9}{|l|}{ SFA } \\
\hline $16: 0$ & $5 \cdot 7^{\mathrm{a}}$ & 0.08 & $6 \cdot 6^{\mathrm{b}}$ & 0.12 & $8.9^{\mathrm{C}}$ & 0.1 & $11 \cdot 1^{d}$ & 0.09 \\
\hline $18: 0$ & $2 \cdot 3^{\mathrm{b}, \mathrm{c}}$ & 0.07 & $2 \cdot 6^{\mathrm{c}}$ & $0 \cdot 10$ & $2 \cdot 2^{\mathrm{b}}$ & 0.13 & $1 \cdot 6^{\mathrm{a}}$ & 0.13 \\
\hline $20: 0$ & 0.00 & 0.00 & $0.62^{\mathrm{a}}$ & 0.04 & $1.6^{\mathrm{b}}$ & 0.05 & $2 \cdot 5^{\mathrm{c}}$ & 0.10 \\
\hline \multicolumn{9}{|l|}{ MUFA } \\
\hline $18: 1 n-9$ & $38 \cdot 4^{d}$ & $1 \cdot 1$ & $36 \cdot 2^{c}$ & 0.57 & $31 \cdot 5^{\mathrm{b}}$ & 0.49 & $22 \cdot 1^{\mathrm{a}}$ & 0.36 \\
\hline $20: 1$ & 0.00 & 0.00 & $3.0^{\mathrm{a}}$ & 0.32 & $6.0^{\mathrm{b}}$ & 0.06 & $11 \cdot 1^{\mathrm{c}}$ & 0.31 \\
\hline $22: 1$ & 0.00 & 0.00 & $1 \cdot 4^{\mathrm{a}}$ & 0.12 & $2 \cdot 2^{\mathrm{b}}$ & 0.04 & $4 \cdot 3^{\mathrm{c}}$ & 0.05 \\
\hline \multicolumn{9}{|l|}{ PUFA } \\
\hline $18: 2 n-6$ & $53 \cdot 6^{d}$ & 0.33 & $40 \cdot 0^{c}$ & 0.63 & $32 \cdot 2^{b}$ & 0.95 & $9.9^{a}$ & 0.21 \\
\hline $18: 3 n-3$ & $0.45^{\mathrm{a}}$ & 0.09 & $8 \cdot 8^{\mathrm{b}}$ & 0.22 & $16 \cdot 7^{c}$ & 0.41 & $32 \cdot 2^{\mathrm{d}}$ & 0.63 \\
\hline$n-6: n-3$ ratio & $105 \cdot 9^{\mathrm{b}}$ & $6 \cdot 7$ & $4 \cdot 6^{\mathrm{a}}$ & 0.15 & $1.9^{a}$ & 0.09 & $0.31^{a}$ & 0.08 \\
\hline
\end{tabular}

SFO10, sunflower oil (SFO) $10 \mathrm{~g} / 100 \mathrm{~g}$; GCO2.5, garden cress seed oil (GCO) $2.5 \mathrm{~g}+\mathrm{SFO} 7.5 \mathrm{~g} / 100 \mathrm{~g} ; \mathrm{GCO} 5, \mathrm{GCO} 5 \mathrm{~g}+\mathrm{SFO}$ $5 \mathrm{~g} / 100 \mathrm{~g} ;$ GCO10, GCO $10 \mathrm{~g} / 100 \mathrm{~g}$.

a,b,c,d Mean values within a row with unlike superscript letters were significantly different $(P<0.05$; ANOVA, a $<$ b $<\mathrm{c}<\mathrm{d})$.

* For details of the diets, see Table 1.

(100 mg/l), $2 \mathrm{mm-L-glutamine} \mathrm{and} 10 \mu \mathrm{M}-2$-mercaptoethanol) in ninety-six-well flat-bottomed culture plates (Nunc, Roskilde, Denmark) in the presence or absence of $5 \mu \mathrm{g} / \mathrm{ml}$ of T-cell mitogens (Con-A and PHA) and a B-cell mitogen (LPS) with triplicate wells for each sample. Cells were incubated in a $\mathrm{CO}_{2}$ incubator at $37^{\circ} \mathrm{C}$ for $72 \mathrm{~h}$. At the 69th hour, $20 \mu \mathrm{l}$ of MTT $(5 \mathrm{mg} / \mathrm{ml})$ prepared in PBS ( $\mathrm{pH} 7 \cdot 4$ ) were added and incubated for $3 \mathrm{~h}$. The plates were spun at $500 \mathbf{g}$, the culture medium was discarded, the solublising reagent dimethyl sulfoxide $(100 \mu \mathrm{l})$ was added and then the absorbance was measured at $550 \mathrm{~nm}$.

\section{IL-2 measurement}

SL were cultured at a cell density of $2.5 \times 10^{5}$ cells/well in complete medium, as described earlier, and stimulated with $5 \mu \mathrm{g}$ of Con-A or PHA for $48 \mathrm{~h}$. Culture medium was aspirated and stored at $-80^{\circ} \mathrm{C}$. Subsequently, the culture medium was thawed, vortexed and centrifuged $\left(4^{\circ} \mathrm{C}\right)$ at $500 \mathrm{~g}$ for $5 \mathrm{~min}$. An aliquot $(50 \mu \mathrm{l})$ of the culture supernatant was analysed quantitatively for IL-2 levels using a commercially available ELISA kit (Quantakine, IL-2; R\&D Systems, Inc.). Results are expressed as pg of $\mathrm{IL} / 2.5 \times 10^{5}$ cells, and data are presented as means with their standard errors $(n 4)$.

\section{Isolation and activation of peritoneal macrophages}

The GCO and SFO diets were fed to rats for 8 weeks. After 8 weeks, rats were injected intraperitoneally with $1 \%$ sodium caseinate in PBS to elicit the migration of macrophages to the peritoneal cavity. After $4 \mathrm{~d}$, rats were anaesthetised with diethyl ether, and peritoneal exudate cells were collected aseptically by irrigating the peritoneal cavity with chilled RPMI-1640 medium. Peritoneal exudates were centrifuged, washed and resuspended in complete RPMI-1640 medium. Cells were seeded at a density of $1 \times 10^{5}$ cells/well in ninety-six-well culture plates (Nunc) and incubated for $2 \mathrm{~h}$ at $37^{\circ} \mathrm{C}$ in a $\mathrm{CO}_{2}$ incubator. Non-adherent cells were removed by washing (three times) with serum-free medium, and adherent cells were cultured overnight in complete medium. More than $95 \%$ of the adherent cell population was found to be peritoneal macrophages (PMФ) as determined by morphology and non-specific esterase staining.

\section{Stimulation of peritoneal macrophages for nitric oxide production}

PMФ $\left(1 \times 10^{5}\right.$ cells/well $)$ were cultured for $12 \mathrm{~h}$ at $37^{\circ} \mathrm{C}$ in a $\mathrm{CO}_{2}$ incubator, and treated with either Con-A $(10 \mu \mathrm{g} / \mathrm{ml})$, PHA $(1 \mu \mathrm{g} / \mathrm{ml})$, LPS $(10 \mu \mathrm{g} / \mathrm{ml})$, A23187 $(1 \mu \mathrm{g} / \mathrm{ml})$ or PMA $(500 \mathrm{ng} / \mathrm{ml})$. Samples were drawn after 6,12 and $24 \mathrm{~h}$ incubation and centrifuged, and the supernatant $(100 \mu \mathrm{l})$ was transferred to ninety-six-well assay plates. Nitrite concentration in the cell-free culture supernatant was measured by a spectrophotometric assay based on the Griess reaction as described elsewhere ${ }^{(18)}$. Briefly, $100 \mu$ l of the culture supernatant were mixed with an equal volume of Griess reagent (one part of $0 \cdot 1 \%(\mathrm{w} / \mathrm{v})$ naphthylethylenediamine dihydrochloride in distilled water and one part of $1 \%(\mathrm{w} / \mathrm{v})$ sulphanilamide in $\left.5 \%(\mathrm{v} / \mathrm{v}) \mathrm{H}_{3} \mathrm{PO}_{4}\right)$ at room temperature. After $15 \mathrm{~min}$, the absorbance was measured using an ELISA plate reader at $540 \mathrm{~nm}$. Nitrite content ( $\mu \mathrm{mol} / 10^{5}$ cells) was quantified using a sodium nitrite standard curve. Determinations were carried out in triplicate $(n 6)$.

\section{Measurement of TNF- $\alpha$}

PMФ $\left(1 \times 10^{5}\right.$ cells/well $)$ in RPMI-1640 medium were treated with LPS $(10 \mu \mathrm{g} / \mathrm{ml})$ in ninety-six-well culture plates (Nunc). After $10 \mathrm{~h}$ incubation at $37^{\circ} \mathrm{C}$ in a $\mathrm{CO}_{2}$ incubator, the cellfree culture supernatant was removed and stored at $-80^{\circ} \mathrm{C}$. An aliquot $(50 \mu \mathrm{l})$ of the culture supernatant was analysed quantitatively for TNF- $\alpha$ using a commercially available ELISA kit (Koma Biotec). Results are expressed as pg of TNF- $\alpha / 1 \times 10^{5}$ cells. Data are expressed as means with their standard errors $(n 4)$. 


\section{Measurement of hydrogen peroxide release}

$\mathrm{H}_{2} \mathrm{O}_{2}$ released in the culture medium by PMФ was determined according to the method of Yaqoob \& Calder ${ }^{(18)}$. PMФ $\left(1 \times 10^{5}\right.$ cells/well) were incubated in $100 \mu \mathrm{l}$ Hanks balanced salt solution containing $0 \cdot 1 \%(\mathrm{w} / \mathrm{v})$ dextrose, $0 \cdot 1 \%$ phenol red and horseradish peroxidase $(40 \mu \mathrm{g} / \mathrm{ml})$. PMA $(10 \mathrm{U} / \mathrm{ml})$ was added and incubated for $2 \mathrm{~h}$ at $37^{\circ} \mathrm{C}$ in a $\mathrm{CO}_{2}$ incubator. The reaction was stopped by the addition of $10 \mu \mathrm{l}$ of $0 \cdot 1 \mathrm{M}-\mathrm{NaOH}$, and the absorbance was measured at $610 \mathrm{~nm}$. Results are expressed as nM of $\mathrm{H}_{2} \mathrm{O}_{2} / 1 \times 10^{5} \mathrm{PM} \Phi . \mathrm{H}_{2} \mathrm{O}_{2}$ concentration was determined by the extinction coefficient $E=43.6 \mathrm{~cm} / \mathrm{m}$.

\section{In vitro lysosomal phosphatase enzyme activity}

Cellular lysosomal phosphatase enzyme activity was determined according to the method described by Manosroi et al. ${ }^{(19)}$. Briefly, PMФ $\left(1 \times 10^{5}\right.$ cells/well $)$ were solubilised

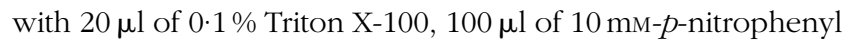
phosphate solution and $50 \mu \mathrm{l}$ of $0 \cdot 1 \mathrm{M}$-citrate buffer $(\mathrm{pH} 5 \cdot 0$ ), and incubated for $30 \mathrm{~min}$ at $37^{\circ} \mathrm{C}$. The reaction was terminated

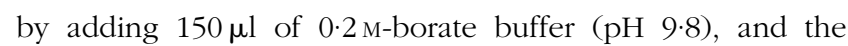
absorbance was measured at $405 \mathrm{~nm}$. Results are expressed as a percentage of lysosomal phosphatase activity.

$$
\text { Lysosomal enzyme activity }=\mathrm{OD}_{\text {sample }}
$$

where OD is optical density.

$$
-\mathrm{OD}_{\text {control }} / \mathrm{OD}_{\text {control }} \times 100
$$

\section{Measurement of leukotriene $B_{4}$}

$\mathrm{LTB}_{4}$ secretion by PM $\Phi$ in response to LPS stimulation was measured by the HPLC method ${ }^{(20)}$. PM $\Phi\left(3 \times 10^{6}\right)$ were incubated with or without $\mathrm{Ca}$ ionophore (A23187) at a concentration of $5 \mu \mathrm{g} / \mathrm{ml}$ in a twenty-four-well culture plate (Nunc) for $90 \mathrm{~min}$ at $37^{\circ} \mathrm{C}$ in a $\mathrm{CO}_{2}$ incubator. The reaction was stopped by adding $30 \mu \mathrm{l}$ of $1 \mathrm{M}-\mathrm{HCl}$ on ice. The supernatants were centrifuged at $2000 \mathrm{~g}$ for $20 \mathrm{~min}$ at $4^{\circ} \mathrm{C}$ and loaded onto Sep-Pack $\mathrm{C}_{18}$ cartridges (Waters Millipore Corporation, Milliford, MA, USA). Leukotrienes were eluted with ethyl acetate. The ethyl acetate fraction was evaporated to dryness, resuspended in methanol and stored at $-80^{\circ} \mathrm{C}$. Identification and quantification of $\mathrm{LTB}_{4}$ was carried out by the HPLC method. A Shimadzu LC-10A HPLC system with a UV detector and a Hypersil reverse-phase C18 column $(150 \times 4.6 \mathrm{~mm} ; 5 \mu \mathrm{m})$ was used. An isocratic elution program was employed using a mobile phase containing methanol-ammonium acetate $(70: 30, \mathrm{v} / \mathrm{v})$. The flow rate was $0.5 \mathrm{ml} / \mathrm{min}$, and the chromatogram was monitored at $280 \mathrm{~nm}$. $\mathrm{LTB}_{4}$ content was quantified based on the calibration curve of standard $\mathrm{LTB}_{4}$ (Sigma Chemicals Company). Results are reported as ng of $\mathrm{LTB}_{4} / 3 \times 10^{6}$ cells. Determinations were done in duplicate $(n 6)$.

\section{Measurement of peritoneal macrophage 5-lipoxygenase} activity

PMФ were suspended in PBS and sonicated for 20-30s at $20 \mathrm{kHz}$ to release the cytosolic 5-lipoxygenase (5-LO) enzyme. This solution was centrifuged at $2000 \boldsymbol{g}$ for $30 \mathrm{~min}$ at $4{ }^{\circ} \mathrm{C}$. The supernatant was used as the source of the enzyme. Protein was estimated by Lowry's method ${ }^{(21)}$ using bovine serum albumin as standard. Assay of 5-LO was performed according to the method of Raghavenra et al. ${ }^{(20)}$. The standard reaction mixture for the 5-LO assay contained $100 \mathrm{~mm}$-phosphate buffer (pH 7.4), 50 mm-dithiothreitol,

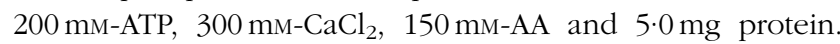
The enzymatic reaction was carried out at $28 \pm 2^{\circ} \mathrm{C}$. Enzyme activity was measured as 5-hydroperoxyeicosatetraenoic acid (5-HETE) formed at $234 \mathrm{~nm}$ using a Shimadzu spectrophotometer. The molar extinction coefficient of $25 / \mathrm{mm} \mathrm{cm}$ was used to calculate the specific activity of 5-LO. Enzyme activity was expressed as $\mu \mathrm{M}-5-\mathrm{HETE} / \mathrm{min}$ per $\mathrm{mg}$ protein. Determinations were done in duplicate $(n 6)$.

\section{Lipid extraction and fatty acid analysis}

Lipids were extracted from SL and PMФ with a chloroformmethanol mixture $(2: 1, \mathrm{v} / \mathrm{v})$. Fatty acid analysis was carried out according to the method of Morisson \& Smith ${ }^{(22)}$. Extracted lipid samples were saponified for $1 \mathrm{~h}$ with $1 \mathrm{ml}$ of $0.7 \mathrm{M}$-methanolic $\mathrm{KOH}$ at $60^{\circ} \mathrm{C}$, followed by neutralisation with $1 \mathrm{ml}$ of methanolic $\mathrm{HCl}(0.7 \mathrm{M})$. The resulting NEFA were extracted with hexane and evaporated to dryness. The fatty acids were methylated using boron trifluoride (14\% in methanol) and $0 \cdot 2 \mathrm{ml}$ benzene. The fatty acid methyl esters were extracted with hexane, washed with water and evaporated to dryness. Fatty acid analysis was performed using a gas-liquid chromatograph (Shimadzu, GC-14B; Shimadzu Corporation, Kyoto, Japan) fitted with a fused silica capillary column (BP 21, $30 \mathrm{~m}$ in length, $0.30 \mathrm{~mm}$ in inner diameter). The gas-liquid chromatograph was equipped with a flame ionisation detector and a Clarity Lite 420 integrator. The column temperature was set at $220^{\circ} \mathrm{C}$, the injector temperature at $230^{\circ} \mathrm{C}$ and the detector temperature at $240^{\circ} \mathrm{C} . \mathrm{N}_{2}$ was used as the carrier gas, and the flow rate was $1 \mathrm{ml} / \mathrm{min}$. Individual fatty acids in the sample were identified by comparison with retention times of standard fatty acid methyl esters. Fatty acid determinations were carried out in duplicate $(n 6)$.

\section{Statistical analysis}

Results were analysed using SPSS-10 software (SPSS, Inc., Chicago, IL, USA). The significance of mean differences between the groups was determined by one-way ANOVA, followed by Duncan's multiple-range test as a post hoc test for multiple comparisons whenever a significant $F$ value emerged. Significance was set at $P<0 \cdot 05$.

\section{Results}

\section{Fatty acid composition of lymphocytes and peritoneal} macrophages

The fatty acid composition of lipids extracted from diets is presented in Table 2 . The $n-6: n-3$ ratio was greatly affected by the addition of GCO in diets. The $n-6: n-3$ ratio was 114.5 in the

\footnotetext{
$20 \mathrm{kHz}$ to release the cytosolic 5 -ipoxygenase (5-LO)
} 
Table 3. Fatty acid composition of spleen lymphocyte $(S L)$ and peritoneal macrophage (PM $\Phi)$ lipids isolated from rats fed with the experimental diets*

(Mean values with their standard errors, $n 6$ )

\begin{tabular}{|c|c|c|c|c|c|c|c|c|c|c|c|c|c|c|c|c|}
\hline \multirow[b]{3}{*}{ Fatty acids (\% total fatty acids) } & \multicolumn{4}{|c|}{ SFO10 } & \multicolumn{4}{|c|}{ GCO2.5 } & \multicolumn{4}{|c|}{ GCO5 } & \multicolumn{4}{|c|}{ GCO10 } \\
\hline & \multicolumn{2}{|c|}{ SL } & \multicolumn{2}{|c|}{ PMФ } & \multicolumn{2}{|c|}{ SL } & \multicolumn{2}{|c|}{ РМФ } & \multicolumn{2}{|c|}{ SL } & \multicolumn{2}{|c|}{ РМФ } & \multicolumn{2}{|c|}{ SL } & \multicolumn{2}{|c|}{ РМФ } \\
\hline & Mean & SEM & Mean & SEM & Mean & SEM & Mean & SEM & Mean & SEM & Mean & SEM & Mean & SEM & Mean & SEM \\
\hline \multicolumn{17}{|l|}{ SFA } \\
\hline $16: 0$ & $27 \cdot 4$ & $2 \cdot 2$ & $31 \cdot 2$ & 1.6 & $26 \cdot 4$ & 1.3 & $30 \cdot 0$ & 1.4 & $25 \cdot 7$ & 0.93 & $30 \cdot 6$ & $1 \cdot 6$ & $28 \cdot 3$ & 0.82 & $31 \cdot 1$ & $1 \cdot 0$ \\
\hline $18: 0$ & $15 \cdot 7$ & $1 \cdot 2$ & $20 \cdot 0$ & 1.5 & $13 \cdot 1$ & 0.48 & $19 \cdot 0$ & $1 \cdot 6$ & $14 \cdot 0$ & 1.2 & $19 \cdot 5$ & $2 \cdot 0$ & $13 \cdot 1$ & 1.4 & $18 \cdot 7$ & $1 \cdot 3$ \\
\hline $20: 0$ & $0.0^{\mathrm{a}}$ & 0.0 & 0.0 & 0.0 & $0.40^{\mathrm{a}}$ & 0.06 & 0.0 & 0.0 & $0 \cdot 18^{a, b}$ & 0.12 & 0.0 & 0.0 & $0.83^{b}$ & 0.30 & 0.0 & $0 \cdot 0$ \\
\hline Total SFA & $43 \cdot 1$ & $2 \cdot 4$ & $51 \cdot 2$ & $2 \cdot 6$ & 39.9 & $1 \cdot 3$ & $49 \cdot 0$ & $2 \cdot 3$ & 39.8 & 1.8 & $50 \cdot 1$ & $3 \cdot 1$ & $42 \cdot 3$ & 1.4 & $49 \cdot 8$ & $2 \cdot 0$ \\
\hline \multicolumn{17}{|l|}{ MUFA } \\
\hline $18: 1 n-9$ & $14 \cdot 0^{\mathrm{a}}$ & 1.6 & $16 \cdot 1$ & 1.0 & $16 \cdot 3^{\mathrm{a}}$ & 1.5 & $18 \cdot 0$ & 1.4 & $14 \cdot 4^{\mathrm{a}}$ & $1 \cdot 1$ & $16 \cdot 3$ & 1.6 & $20 \cdot 6^{\mathrm{b}}$ & 0.85 & $19 \cdot 6$ & 0.91 \\
\hline $20: 1 n-9$ & $0 \cdot 0^{\mathrm{a}}$ & 0.0 & $0.27^{\mathrm{a}}$ & 0.09 & $1 \cdot 7^{\mathrm{b}}$ & $0 \cdot 14$ & $0.57^{\mathrm{a}}$ & 0.18 & $2 \cdot 1^{\mathrm{b}}$ & 0.31 & $1 \cdot 2^{\mathrm{b}}$ & 0.22 & $2 \cdot 4^{\mathrm{b}}$ & 0.36 & $1.4^{\mathrm{b}}$ & 0.29 \\
\hline Total MUFA & $14 \cdot 0^{\mathrm{a}}$ & 1.3 & $16 \cdot 4^{a}$ & $1 \cdot 1$ & $18 \cdot 1^{b}$ & 1.4 & $18 \cdot 6^{a, b}$ & 1.5 & $16 \cdot 5^{\mathrm{a}, \mathrm{b}}$ & 1.3 & $17 \cdot 5^{\mathrm{a}, \mathrm{b}}$ & 1.7 & $23 \cdot 6^{c}$ & 1.0 & $21.5^{\mathrm{b}}$ & 1.0 \\
\hline \multicolumn{17}{|l|}{ PUFA } \\
\hline $18: 2 n-6$ & $15 \cdot 3^{b}$ & 1.8 & $9 \cdot 7^{\mathrm{b}}$ & 0.32 & $14 \cdot 7^{\mathrm{b}}$ & 0.96 & $9.9^{\mathrm{b}}$ & 1.3 & $13 \cdot 7^{b}$ & 0.73 & $8 \cdot 2^{a, b}$ & $1 \cdot 1$ & $9 \cdot 4^{\mathrm{a}}$ & 0.91 & $7 \cdot 0^{\mathrm{a}}$ & 0.26 \\
\hline $20: 4 n-6$ & $17 \cdot 1^{\mathrm{c}}$ & 0.93 & $16 \cdot 8^{\mathrm{b}}$ & $1 \cdot 6$ & $14 \cdot 3^{b, c}$ & 1.0 & $15 \cdot 1^{\mathrm{a}, \mathrm{b}}$ & $2 \cdot 4$ & $13 \cdot 1^{a, b}$ & 0.58 & $13 \cdot 5^{\mathrm{a}, \mathrm{b}}$ & 1.5 & $11 \cdot 1^{\mathrm{a}}$ & $1 \cdot 1$ & $10 \cdot 2^{\mathrm{a}}$ & 1.9 \\
\hline Total $n-6$ PUFA & $32 \cdot 4^{\mathrm{C}}$ & 1.0 & $26 \cdot 6^{\mathrm{b}}$ & 1.5 & $29 \cdot 0^{\mathrm{b}}$ & 0.8 & $23 \cdot 3^{a, b}$ & 3.1 & $26 \cdot 8^{\mathrm{b}}$ & 0.9 & $21 \cdot 6^{a, b}$ & 1.6 & $20.5^{\mathrm{a}}$ & 1.4 & $17 \cdot 2^{\mathrm{a}}$ & 1.8 \\
\hline $18: 3 n-3$ & $0.0^{\mathrm{a}}$ & 0.0 & $0.0^{\mathrm{a}}$ & 0.0 & $0.43^{\mathrm{a}, \mathrm{b}}$ & 0.05 & $0.30^{\mathrm{a}, \mathrm{b}}$ & 0.09 & $1.0^{\mathrm{b}}$ & 0.12 & $0.60^{\mathrm{b}}$ & 0.15 & $3 \cdot 2^{\mathrm{c}}$ & 0.49 & $0.97^{c}$ & 0.2 \\
\hline $20: 5 n-3$ & $0.0^{\mathrm{a}}$ & 0.0 & $0.0^{\mathrm{a}}$ & 0.0 & $0.56^{\mathrm{b}}$ & 0.05 & $0.51^{a, b}$ & 0.14 & $0.56^{\mathrm{b}}$ & 0.02 & $0.77^{b, c}$ & 0.27 & $1.7^{\mathrm{c}}$ & 0.14 & $1 \cdot 1^{\mathrm{c}}$ & 0.2 \\
\hline $22: 6 n-3$ & $0.0^{\mathrm{a}}$ & 0.0 & $0.0^{\mathrm{a}}$ & 0.0 & $0.68^{\mathrm{b}}$ & 0.08 & $0.0^{\mathrm{a}}$ & 0.0 & $0.97^{b}$ & 0.09 & $0.60^{\mathrm{b}}$ & 0.07 & $1.7^{\mathrm{c}}$ & 0.24 & $1 \cdot 6^{\mathrm{C}}$ & 0.17 \\
\hline Total $n$-3 PUFA & $0.0^{a}$ & 0.0 & $0.00^{\mathrm{a}}$ & 0.00 & $1 \cdot 7^{\mathrm{b}}$ & 0.10 & $0.80^{\mathrm{a}}$ & 0.2 & $2 \cdot 5^{\mathrm{b}}$ & 0.15 & $2 \cdot 0^{\mathrm{b}}$ & 0.3 & $6 \cdot 6^{c}$ & 0.55 & $3 \cdot 6^{c}$ & 0.45 \\
\hline Total PUFA & $32 \cdot 4$ & $1 \cdot 0$ & $26 \cdot 6$ & 1.5 & $30 \cdot 6$ & 0.84 & $24 \cdot 1$ & 3.2 & $29 \cdot 3$ & 0.94 & $23 \cdot 6$ & $1 \cdot 8$ & $27 \cdot 1$ & $1 \cdot 2$ & $20 \cdot 8$ & 1.9 \\
\hline$n-6: n-3$ ratio & - & - & - & - & $17 \cdot 6^{\mathrm{c}}$ & 0.90 & $33.0^{\mathrm{b}}$ & $4 \cdot 2$ & $10 \cdot 9^{b}$ & 0.6 & $12 \cdot 7^{\mathrm{a}}$ & $2 \cdot 4$ & $3 \cdot 2^{\mathrm{a}}$ & 0.4 & $5 \cdot 1^{\mathrm{a}}$ & 0.86 \\
\hline
\end{tabular}

SFO10, sunflower oil (SFO) $10 \mathrm{~g} / 100 \mathrm{~g}$; GCO2.5, garden cress seed oil (GCO) $2.5 \mathrm{~g}+$ SFO 7.5 g/100 g; GCO5, GCO $5 \mathrm{~g}+$ SFO 5 g/100 g; GCO10, GCO 10 g/100 g

a,b,c Mean values within a row with unlike superscript letters were significantly different: $(P<0.05 ;$ ANOVA, a $<\mathrm{b}<\mathrm{c})$.

* For details of the diets see Table 1 and for procedures see Materials and methods. 
SFO10 diet. The ratio decreased to $4.6,1.9$ and 0.3 , respectively, in the GCO2.5, GCO5 and GCO10 diets.

The fatty acid composition of lipids extracted from SL and PMФ is presented in Table 3. SFA $(16: 0+18: 0)$ content in SL and PM $\Phi$ did not change among the dietary groups. However, an increase of 51.4 and $27.9 \%$ was observed in MUFA levels in both SL and PM $\Phi$, respectively, in the GCO10 group compared with the SFO10 group. ALA, EPA and DHA contents increased by $3.2,1.72,1.7 \%$ in SL lipids and 0.97 , $1.08,1.6 \%$ in PMФ lipids, respectively, in the GCO groups compared with the SFO10 group. LA and AA content was decreased by 28.05 and $39.5 \%$ in $P M \Phi$, and 38.35 and $35.37 \%$ in SL, respectively, in the GCO10 group compared with the SFO10 group (Table 3).

\section{Lymphocyte proliferation and IL-2 production}

The effect of the experimental diets on SL proliferation is summarised in Fig. 1. SL proliferation induced by Con-A and PHA was significantly inhibited in the GCO groups. GCO at $2.5 \%$ caused a 40 and $36 \%$ reduction in the proliferation of SL induced by Con-A and PHA, respectively. An insignificant decrease was observed in the proliferation of SL induced by LPS in the GCO10 group (1.06 (SEM 0.09)) compared with the SFO10 group (1.95 (SEM 0.42)). A marginal decrease in IL-2 levels was observed in SL stimulated with Con-A in the GCO10 group (21.32 (SEM 1.9) pg/2.5 $\times 10^{5}$ cells) compared with the SFO10 group (22.5 (SEM 1.0$) \mathrm{pg} / 2.5 \times 10^{5}$ cells).

\section{Nitric oxide release by peritoneal macrophages}

A stable end product, nitrite, was determined to measure NO release in РМФ. Nitrite content at different time intervals (6, 12 and $24 \mathrm{~h}$ ) after post-stimulation of PM $\Phi$ with Con-A, LPS,
A23187, PHA and PMA is presented in Fig. 2. In the GCO groups, a significant decrease in nitrite production was observed at $12 \mathrm{~h}$ post-treatment with Con-A, PHA and A23187 (Fig. 2(a)-(c), respectively) compared with the SFO10 group. However, a significant decrease in nitrite content was observed at 6, 12 and 24h in PHA-treated PMФ, in all GCO groups. A non-significant downward trend was observed in nitrite production in LPS- and PMA-stimulated PMФ (Fig. 2(d) and (e), respectively) in GCO-fed rats.

\section{TNF- $\alpha$ and leukotriene $B_{4}$ release by peritoneal macrophages}

Concentration of TNF- $\alpha$ released by $P M \Phi$ after $10 \mathrm{~h}$ poststimulation of LPS did not differ much between the GCO10 (125 (SEM 6.9) pg/1 × $10^{5}$ cells) and SFO10 (145 (SEM 3.0) pg/ $1 \times 10^{5}$ cells) groups. Concentration of $\mathrm{LTB}_{4}$ released by PM $\Phi$ in response to A23187 stimulation was measured using reverse-phase HPLC and is depicted in Fig. 3. $\mathrm{LTB}_{4}$ content was reduced significantly in the GCO5 and GCO10 groups compared with the SFO10 group.

\section{Leukotriene $B_{4}$ release by peritoneal macrophages}

Concentration of TNF- $\alpha$ released by PMФ after $10 \mathrm{~h}$ of poststimulation of LPS did not differ much between the GCO and SFO groups. Concentration of $\mathrm{LTB}_{4}$ released by PMФ in response to A23187 stimulation was measured using reversephase HPLC and is depicted in Fig. 3. $\mathrm{LTB}_{4}$ content was reduced significantly in the GCO5 (17.0 (SEM 0.9) $\mathrm{ng} / 3 \times 10^{6}$ cells) and GCO10 groups (12.0 (SEM $1 \cdot 0) \mathrm{ng} / 3 \times 10^{6}$ cells) compared with the SFO10 group (20.0 (

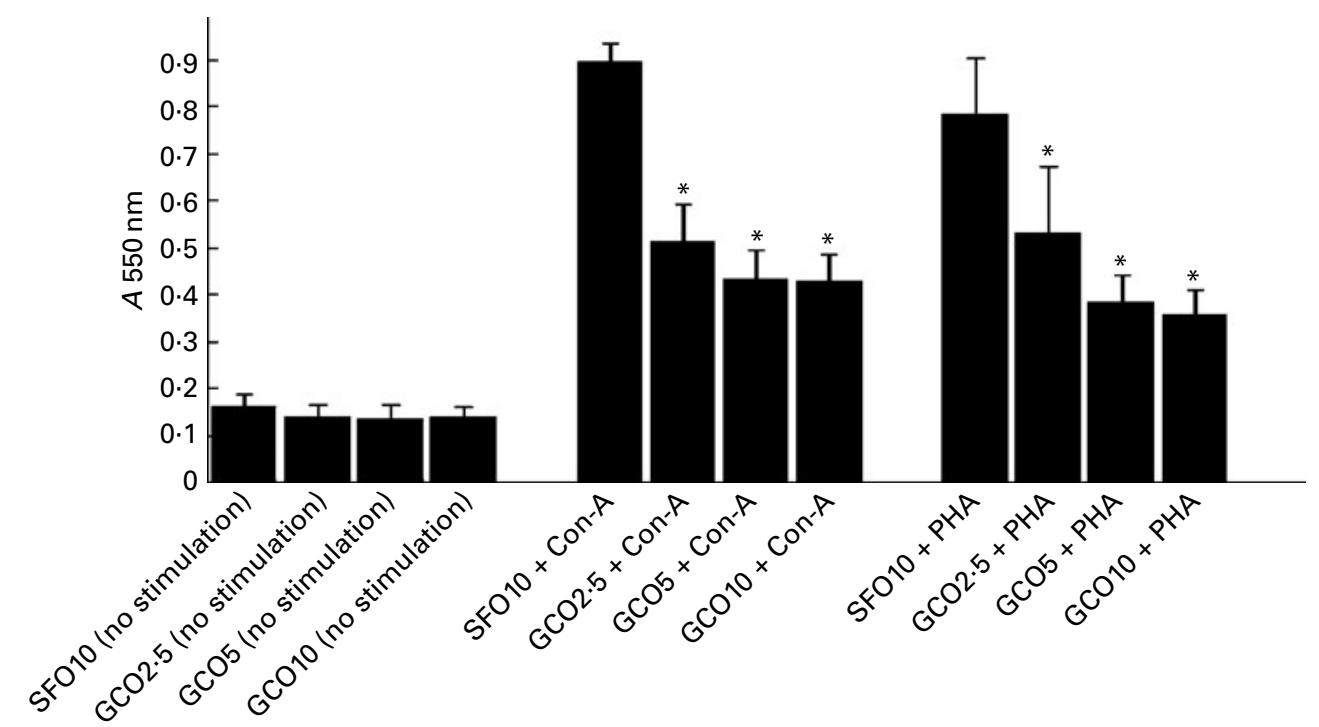

Fig. 1. Effect of dietary lipids on the proliferation of spleen lymphocytes stimulated with concanvalin-A (Con-A, $5 \mu \mathrm{g} / \mathrm{ml})$ or phytohaemagglutinin (PHA, $5 \mu \mathrm{g} / \mathrm{ml})$. Rats were fed with the sunflower oil (SFO)- and garden cress seed oil (GCO)-supplemented diets for 8 weeks as described in Materials and methods. Spleen lymphocytes $\left(1.5 \times 10^{5}\right.$ cells/well) were isolated and cultured for $72 \mathrm{~h}$ in Roswell Park Memorial Institute-1640 complete medium and $2.5 \%$ autologous serum in the presence or absence of mitogens. The amount of formazan formed by the cells was measured spectrophotometrically at $550 \mathrm{~nm}$. Values are means, with their standard errors represented by vertical bars $(n 6)$. ${ }^{*}$ Mean values were significantly different compared with the SFO $10 \mathrm{~g} / 100 \mathrm{~g}$ group $(P<0.05)$. $A$, absorbance. 

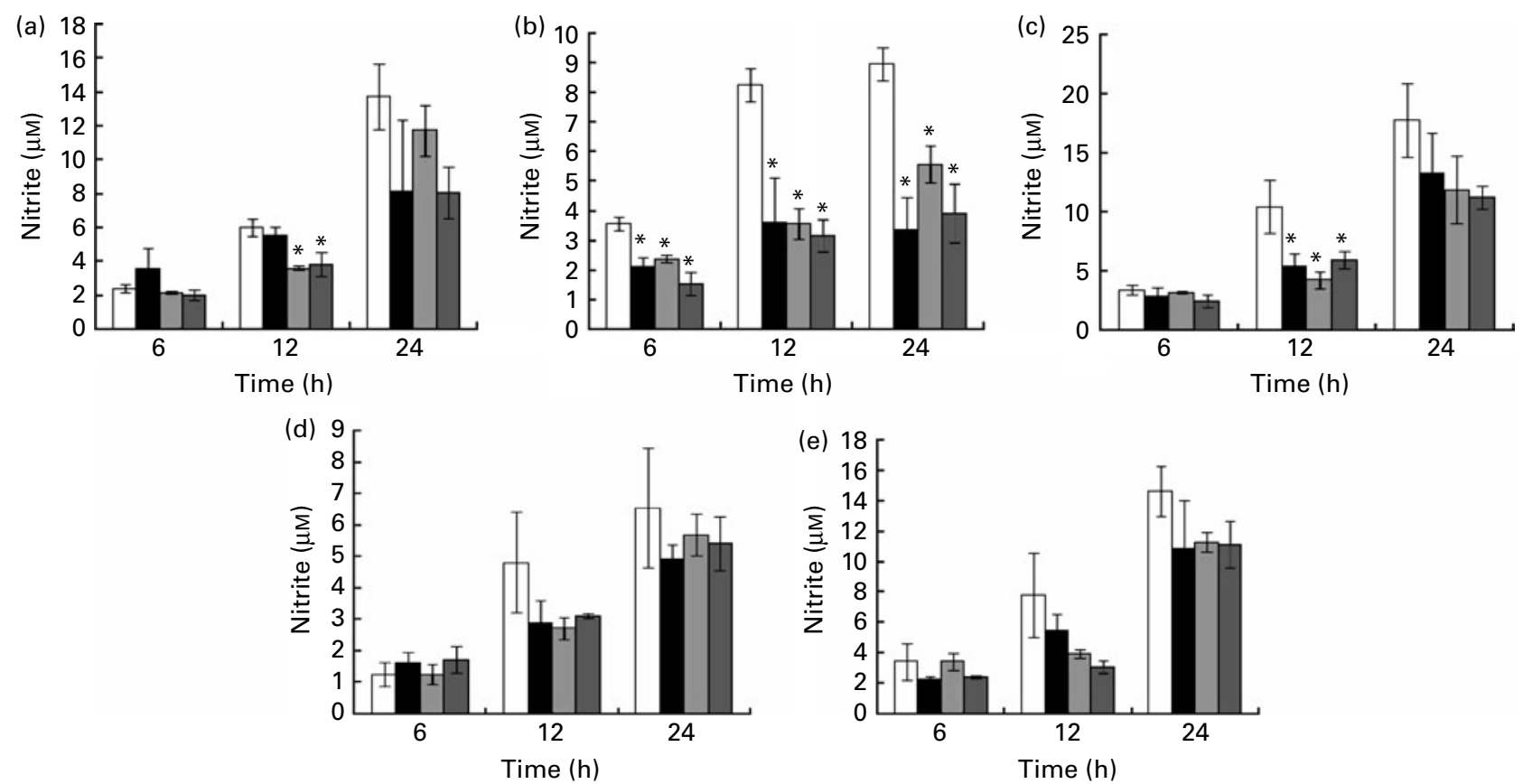

Fig. 2. Effect of dietary lipids on nitric oxide produced by rat peritoneal macrophages (РМФ). РМФ from rats fed with the experimental diets for 8 weeks were stimulated ex vivo with (a) concanvalin-A $(10 \mu \mathrm{g} / \mathrm{ml})$, (b) phytohaemagglutinin $(1 \mu \mathrm{g} / \mathrm{ml})$, (c) calcium ionophore $(1 \mu \mathrm{g} / \mathrm{ml})$, (d) lipopolysaccharide (10 $\mu \mathrm{g} / \mathrm{ml})$ and $(100 \mathrm{mg} / \mathrm{l})(\mathrm{e})$ phorbol 12-myristate 13 -acetate $(0.5 \mu \mathrm{g} / \mathrm{ml})$. Culture supernatants were removed after 6,12 and $24 \mathrm{~h}$ post-treatment of mitogens. Concentration of nitrite in the medium was measured by the Griess method. Values are means, with their standard errors represented by vertical bars ( $n$ 6). ${ }^{*}$ Mean values were significantly different compared with the $10 \mathrm{~g} / 100 \mathrm{~g}$ sunflower oil group (SFO10); $P<0.05$. $\square$, SFO10; $\mathbf{a}$, garden cress seed oil (GCO)2.5; $\square$, GCO5; $\square$, GCO10.

\section{Hydrogen peroxide release by stimulated peritoneal macrophages}

No significant difference was observed in $\mathrm{H}_{2} \mathrm{O}_{2}$ levels released by

\section{Acid phosphatase and 5-lipoxygenase activity in peritoneal macrophages}

Acid phosphatase and 5-LO activities in PMФ were unaltered among the different GCO groups.

\section{Discussion}

PM $\Phi$ and SL are key cells of the immune system involved in host defence, inflammation and immune response. Since the action of these cells is mediated by membrane-bound components, an alteration in the membrane lipid composition could modulate immune function. It is known that dietary lipids can affect the fatty acid composition of immunocompetent cells. In the present study, we demonstrated that partial or complete replacement of LA (18:2n-6) with ALA $(18: 3 n-3)$ in diets through GCO can alter the fatty acid composition and modulate inflammatory mediators produced by PM $\Phi$ and SL.

Immunocompetent cells (PM $\Phi$ and $\mathrm{SL}$ ) originate in the bone marrow. Lymphocytes mature in primary lymphoid tissues and stay in peripheral lymphoid organs to keep a vigil on invading microbes. Rapidly dividing promonocytes are progenitor cells of blood monocytes, which give rise to PMФ. When stimulated, blood monocytes divide rapidly and move to the peritoneal cavity as $\mathrm{PM} \Phi^{(23)}$. The type and amount of fatty acids in the blood fatty acid pool during blastogenesis determine the fatty acid profile of PMФ. Earlier studies have shown an increase in the ALA content of PM $\Phi$ and SL in rats fed with flaxseed and perilla oil. These oils contain 55-56\% of ALA, 13 and $18 \%$ of LA and a $n-6: n-3$ ratio of $0 \cdot 24$ and $0 \cdot 32$, respectively $^{(11,14,24)}$. Lymphocytes are cells that specifically recognise and respond to foreign antigens. In response to stimuli, T-lymphocytes secrete cytokines and undergo cell division ${ }^{(25)}$. Proliferation of lymphocytes leads to an increase in the number of antigen-specific lymphocytes and the activation of B-lymphocytes, natural killer cells and macrophages. Therefore, proliferation is a key process in the regulation, amplification and memory of the cell-mediated immune response ${ }^{(25)}$. In the present study, a significant decrease was observed in the ex vivo proliferation of lymphocytes in response to Con-A or PHA stimuli in the GCO groups. Substitution of SFO with $50 \%$ GCO in the diet significantly decreased the proliferation of SL. A further increase in GCO in the diet had no additive effect on the proliferation of lymphocytes. A similar effect has been observed when a small amount of SFO was replaced by linseed oil ( $n-6: n-3$ PUFA ratio of 14.75$)$ in the diet of rats $^{(11)}$. An ALA-rich diet has been reported to decrease the ex vivo proliferation of blood lymphocytes in response to mitogenic stimuli in poultry, rats and human subjects ${ }^{(13,26-29)}$. The exact mechanisms by which $n$-3 PUFA modulate lymphocyte proliferation are far from clear, but certain mechanisms have been suggested. A decreased expression in IL-2 in activated lymphocytes by $n-3$ fatty acids has been suggested for the inhibition of lymphocyte proliferation. However, in the present study, we observed no significant change in the IL-2 


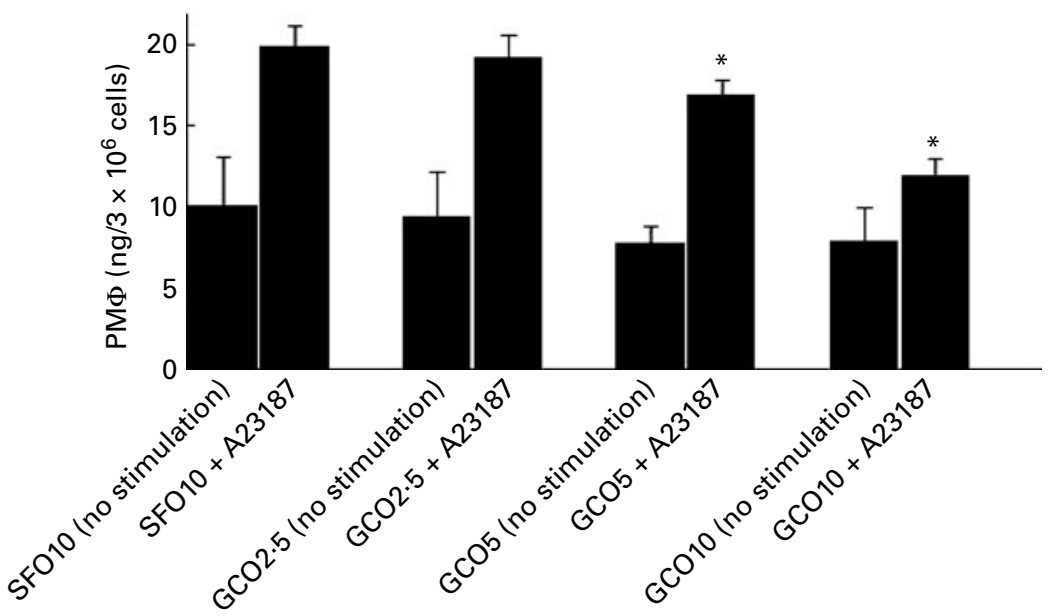

Fig. 3. Effect of dietary lipids on leukotriene $B_{4}$ production by peritoneal macrophages (PM $\Phi, 3 \times 10^{6}$ cells/ml) stimulated with calcium ionophore (A23187, $5 \mu \mathrm{g} / \mathrm{ml}$ ). Rats were fed with the sunflower oil (SFO)- and garden cress seed oil (GCO)-supplemented diets as described in Materials and methods. PM $\Phi$ were isolated and incubated for $90 \mathrm{~min}$ in Roswell Park Memorial Institute-1640 complete medium with $2.5 \%$ autologous serum in the presence or absence of A23187 $(5 \mu \mathrm{g} / \mathrm{ml})$. Leukotriene $B_{4}$ in the culture supernatant was analysed by reverse-phase HPLC as described in Materials and methods. Values are means, with their standard errors represented by vertical bars $(n 6)$. ${ }^{*}$ Mean values were significantly different compared with the SFO group $(10 \mathrm{~g} / 100 \mathrm{~g})(P<0.05)$.

of lymphocytes in GCO-fed rats. Earlier studies with fish oil (EPA and DHA) have reported a decrease in IL-2 levels ${ }^{(30,31)}$ and or no effect on IL-2 production in lymphocytes of rats and human subjects ${ }^{(29,32-35)}$. However, a decreased expression in IL-2 receptors has been suggested to play a role in the suppression of lymphocyte proliferation ${ }^{(36)}$. LCPUFA in fish oil have been reported to differentially modulate T-cell rafts and soluble membrane phospholipids, causing a displacement of acylated proteins from rafts $^{(4,37)}$. When T-cells are activated, protein kinase $\mathrm{C} \theta$, phospholipase $\mathrm{C}-\boldsymbol{\gamma}$, linker for the activation of T-cells are translocated to lipid rafts, which induce the proliferation of lymphocytes ${ }^{(38,39)}$. The conditions that modify the integrity of T-cell rafts can disrupt the early steps of T-cell activation ${ }^{(40)}$. Therefore, the incorporation of $n-3$ PUFA into the membrane microdomain may influence signal transduction and modulate T-cell activation $^{(4)}$.

PMФ constitute a major group of phagocytic leucocytes, which are crucial to immune surveillance against invading pathogens. Activated PM $\Phi$ release an array of mediators including pro-inflammatory cytokines (TNF- $\alpha$, IL-1 and IL-6), growth factors, bioactive eicosanoids ( $\mathrm{LTB}_{4}, \mathrm{PGE}_{2}$ and thromboxane $\mathrm{A}_{2}$ ), hydrolytic enzymes (peroxidase and protease), reactive oxygen intermediates and NO. Each of the above secretory molecules is implicated in the pathogenesis of chronic inflammatory conditions and considered as pharmacological targets of inflammatory diseases. In the present study, we assessed the effect of dietary GCO on inflammatory mediators released by PMФ. NO is considered as one of the principal effector molecules in $\mathrm{PM} \Phi$-mediated cytotoxicity ${ }^{(41)}$. The amount of NO released by PMФ isolated from the GCO group of rats was significantly reduced in comparison with NO released by PMФ of the SFO group. The percentage of reduction was found to be 57,62 and $56 \%$, respectively, after 6, 12 and $24 \mathrm{~h}$ post-stimulation of PHA. NO release was also significantly reduced by 37 and $44 \%$, respectively, at
$12 \mathrm{~h}$ post-stimulation with Con-A and A23187 in the GCO10 group compared with the SFO10 group. Previous studies have shown decreased ${ }^{(42,43)}$, increased or no change in the production of NO by the PM $\Phi$ of animals fed with fish oil $^{(18,30,44,45)}$ and linseed oil ${ }^{(46)}$. Dietary LCPUFA have been reported to decrease the expression of inducible NO synthase in cancer cells and LPS-stimulated RAW 264.7 macrophages ${ }^{(47,48)}$. Ren \& Chung ${ }^{(49)}$ reported that ALA markedly inhibits LPS-induced $\mathrm{NO}$ production and inducible $\mathrm{NO}$ synthase gene expressions by blocking NF-кB activation and also the phosphorylation of mitogen-activated protein kinases in RAW 264.7 macrophages. In the present study, macrophages were cultured with $2.5 \%$ of autologous serum from the respective SFO- and GCO-fed rats. In a previous study, serum from GCO2.5-, GCO5- and GCO10-fed rats contained $2 \cdot 2,4.5$ and $8.3 \%$ of ALA, $0.8,1.2$ and $5.4 \%$ of EPA and 1.72 , 2.9 and $2.7 \%$ of DHA, respectively ${ }^{(10)}$. Thus, the exogenous pool of $n$-3 PUFA added to PM $\Phi$ might play an important role in the reduction of $\mathrm{NO}$ observed in the present study. Furthermore, it has been reported that $\gamma$-tocopherol can also inhibit inducible NO synthase in activated macrophages ${ }^{(50)}$ Since GCO contains high amount of $\gamma$-tocopherol $(87.74 \mathrm{mg} /$ $100 \mathrm{~g})^{(16)}$, we hypothesise that the decrease in NO production in ex vivo-stimulated $\mathrm{PM} \Phi$ can be attributed to the additive effect of ALA and $\gamma$-tocopherol present in GCO. However, further studies are needed to elucidate the mechanism of modulation of inducible NO synthase and NO production by physiological concentrations of ALA and $\gamma$-tocopherol.

The SFO (18:2n-6)-rich diet increased the levels of AA in PM $\Phi$ lipids. A concomitant increase in $\mathrm{LTB}_{4}$ was observed in A23187-stimulated PMФ. On the contrary, the GCO10 diet reduced $\mathrm{AA}$ and $\mathrm{LTB}_{4}$ levels by 38 and $40 \%$, respectively, in PMФ lipids. Leukotrienes are synthesised by the 5-LO pathway, and their activity was unaltered in the PMФ of rats fed with the SFO and GCO diets. Therefore, the decrease in $\mathrm{LTB}_{4}$ observed in the present study can be attributed to the 
decrease in AA levels in the cellular lipids of PMФ in GCO-fed rats. Since $\mathrm{LTB}_{4}$ is a potent chemotactic agent, recruits immune cells at the site of injury and orchestrates inflammatory events leading to tissue damage, modulating its levels by $n-3$ fatty acids may be beneficial in chronic inflammatory conditions.

Phagocytosis by polymorphonuclear leucocytes or PMФ results in increased oxygen consumption and production of reactive oxygen intermediates, which contribute to the microbicidal action of these immunocompetent cells ${ }^{(51)}$. Furthermore, lysosomal acid phosphatase activity is 0thg f32\#considered as a marker and correlates with the bactericidal action of macrophages ${ }^{(52)}$. Therefore, we investigated the effect of SFO or GCO on $\mathrm{H}_{2} \mathrm{O}_{2}$ release and in vitro lysosomal phosphatase enzyme activity in PMA-stimulated PMФ. The ex vivo release of $\mathrm{H}_{2} \mathrm{O}_{2}$ and lysosomal phosphatase activity were not affected in the PMФ of rats fed with SFO or GCO. This observation shows that GCO may not modulate the bactericidal activity of macrophages.

\section{Conclusion}

We report that dietary supplementation of GCO increased ALA, EPA and DHA levels in the membrane lipids of immunocompetent cells. GCO significantly suppressed the ex vivo proliferation of SL in response to stimulation by $\mathrm{T}$-cell mitogens with little or no effect on IL-2 secretion. GCO suppressed the release of inflammatory mediators such as $\mathrm{LTB}_{4}$, NO and, to a lesser extent, TNF- $\alpha$ in activated PMФ. Our data add further evidence that dietary supplementation of ALA alters the lipid composition of immune cells and modulates certain inflammatory mediators in normal rats. However, further studies are needed to understand the long-term effect of ALA in the modulation of inflammatory mediators in ulcerative colitis, arthritis, asthma and allergic disorders.

\section{Acknowledgements}

The authors thank Dr V. Prakash, Director, Central Food Technological Research Institute, and Dr P. V. Salimath, Head of the Department of Biochemistry and Nutrition, for their encouragement and support. K. A. N. gratefully acknowledges the financial assistance in the form of a project from the Indian Council of Medical Research, New Delhi. Financial support to B. T. D. through a Senior Research Fellowship from the Council for Scientific and Industrial Research, New Delhi, India, is also gratefully acknowledged. There are no conflicts of interest whatsoever among the authors. B. T. D. was responsible for conducting the experiments. K. A. N. supervised the experiments and prepared the manuscript. B. R. L. helped in the interpretation of the results and preparation of the manuscript.

\section{References}

1. Clandinin MT, Cheema S, Field CJ, et al. (1991) Dietary fat: exogenous determination of membrane structure and cell function. FASEB J 5, 2761-2769.
2. Calder PC (1998) Dietary fatty acids and lymphocyte functions. Proc Nutr Soc 57, 487-502.

3. Simopoulos AP (2002) The importance of the ratio of omega6/omega-3 essential fatty acids. Biomed Pharmacother 56, $365-379$.

4. Fan YY, McMurray DN, Ly LH, et al. (2003) Dietary (n-3) polyunsaturated fatty acids remodel mouse T-cell lipid rafts. J Nutr 133, 1913-1920.

5. Li Q, Wang M, Tan L, et al. (2005) Docosahexaenoic acid changes lipid composition and interleukin-2 receptor signaling in membrane rafts. J Lipid Res 46, 1904-1913.

6. Bouwens M, Rest O, Dellschaft, et al. (2009) Fish-oil supplementation induces antiinflammatory gene expression profiles in human blood mononuclear cells. Am J Clin Nutr 90, 415-424.

7. Burdge GC, Jones AE \& Wooton SA (2002) Eicosapentaenoic and docosapentaenoic acids are the principal products of $\alpha$-linolenic acid metabolism in young men. Br J Nutr $\mathbf{8 8}$, 355-363.

8. Pawlosky RJ, Hibbeln JR, Novotny JA, et al. (2001) Physiological compartmental analysis of $\alpha$-linolenic acid metabolism in adult humans. J Lipid Res 42, 1257-1265.

9. Morisea A, Combeb N, Bouéb C, et al. (2004) Dose effect of $\alpha$-linolenic acid on PUFA conversion, bioavailability and storage in the hamster. Lipids 39, 325-334.

10. Diwakar BT, Dutta PK, Lokesh BR, et al. (2008) Bioavailability and metabolism of $n$ - 3 fatty acid rich garden cress (Lepidium sativum) seed oil in albino rats. Prostaglandins Leukot Essent Fatty Acids 78, 123-130.

11. Jeffery NM, Sanderson P, Sherrington EJ, et al. (1996) The ratio of $n-6$ to $n-3$ polyunsaturated fatty acids in the rat diet alters serum lipid levels and lymphocyte functions. Lipids 31, 737-745.

12. Coblijn GB, Murphy EJ, Othman R, et al. (2009) Flaxseed oil and fish-oil capsule consumption alters human red blood cell $n$-3 fatty acid composition: a multiple-dosing trial comparing 2 sources of $n-3$ fatty acid. Am J Clin Nutr 88, 801-809.

13. Kelley DS, Branch LB, Love JE, et al. (1991) Dietary ( $\alpha$-linolenic acid and immunocompetence in humans. Am J Clin Nutr 53, 40-46.

14. Caughey GE, Mantzioris E, Gibson RA, et al. (1996) Interleukin 1 production of diets enriched in $n-3$ fatty acids from vegetable oil or fish oil. Am J Clin Nutr 63, 116-122.

15. Mizota T, Kambara CF, Matsuya N, et al. (2009) Effect of dietary fatty acid composition on Th1/Th2 polarization in lymphocytes. J Parent Enteral Nutr 33, 390-396.

16. Diwakar BT, Dutta PK, Lokesh BR, et al. (2010) Physicochemical properties of $\omega-3$ fatty acid rich garden cress (Lepidium sativum L.) seed oil. J Am Oil Chem Soc 87, 539-548.

17. Sladowski D, Steer SJ, Clothier RH, et al. (1993) An improved MTT assay. J Immunol Methods 157, 203-207.

18. Yaqoob P \& Calder P (1995) Effects of dietary lipid manipulation upon inflammatory mediator production by murine macrophages. Cell Immunol 163, 120-128.

19. Manosroi A, Saraphanchotiwitthaya A \& Manosroi J (2003) Immunomodulatory activities of Clausena excavate Burm. f. wood extracts. J Ethnopharmacol 89, 155-160.

20. Raghavenra H, Diwakra BT, Lokesh BR, et al. (2006) Eugenol - the active principle from cloves inhibits 5-lipoxygenase activity and leukotriene- $\mathrm{C}_{4}$ in human PMNL cells. Prostaglandins Leukot Essent Fatty Acids 74, 23-27.

21. Lowry $\mathrm{OH}$, Rosebrough NJ, Farr A, et al. (1951) Protein measurement with Folin phenol reagent. J Biol Chem 143, $265-271$. 
22. Morisson WR \& Smith LM (1964) Preparation of fatty acid methyl esters and dimethylacetals from lipids with boron fluoride methanol. J Lipid Res 5, 600-608.

23. Furth RV \& Colin ZA (1968) The origin and kinetics of mononuclear phagocytes. J Exp Med 128, 415-435.

24. Kaku S, Yunoki SI, Ohkura KI, et al. (2001) Interactions of dietary fats and proteins on fatty acid composition of immune cells and $\mathrm{LTB}_{4}$ production by peritoneal exudate cells of rats. Biosci Biotechnol Biochem 65, 315-321.

25. Abbas AK, Lichtman AH \& Pober JS (1994) Cellular and Molecular Immunology. Philadelphia, PA: WB Saunders.

26. Wang YW, Field CJ \& Sim JS (2000) Dietary polyunsaturated fatty acids alter lymphocyte subset proportion and proliferation, serum immunoglobulin $G$ concentration, and immune tissue development in chicks. Poult Sci 79, 1741-1748.

27. Jeffery NM, Newsholme EA \& Calder PC (1997) The level of polyunsaturated fatty acids and the $n-6$ to $n-3$ polyunsaturated fatty acid ratio in the rat diet both affect serum lipid levels and lymphocyte functions. Prostaglandins Leukot Essent Fatty Acids 57, 149-160.

28. Calder PC, Costa-Rosa LF \& Curi R (1994) Effects of feeding lipids of different fatty acid compositions upon rat lymphocyte proliferation. Life Sci 56, 455-463.

29. Thies F, Nebe-von-Caron G, Powell JR, et al. (2001) Dietary supplementation with $\gamma$-linolenic acid or fish oil decreases $\mathrm{T}$ lymphocyte proliferation in healthy older humans. $J$ Nutr 131, 1918-1927.

30. Turek JJ, Schoenlein IA, Clark LK, et al. (1994) Dietary polyunsaturated fatty acids effects on immune cells of the porcine lung. J Leukoc Biol 56, 599-604.

31. Wallace FA, Miles EA, Evans C, et al. (2001) Dietary fatty acids influence the production of Th1- but not Th2-type cytokines. J Leukoc Biol 69, 449-457.

32. Meydani SN, Lichtenstein AH, Cornwall S, et al. (1993) Immunologic effects of national cholesterol education panel step-2 diets with and without fish-derived $n-3$ fatty acid enrichment. J Clin Invest 92, 105-113.

33. Yaqoob P, Pala HS, Cortina-Borja M, et al. (2000) Encapsulated fish oil enriched in $\alpha$-tocopherol alters plasma phospholipid and mononuclear cell fatty acid compositions but not mononuclear cell functions. Eur J Clin Invest 30, 260-274.

34. Endres S, Meydani SN, Ghorbani R, et al. (1993) Dietary supplementation with $n$-3 fatty acids suppresses interleukin-2 production and mononuclear cell proliferation. I Leukoc Biol 54, 599-603.

35. Babu US, Wiesenfeld PW, Collins TFX, et al. (2003) Impact of high flaxseed diet on mitogen-induced proliferation, IL-2 production, cell subsets and fatty acid composition of spleen cells from pregnant and F1 generation SpragueDawley rats. Food Chem Toxicol 41, 905-915.

36. Jolly CA, Mac Murray DN \& Chapkin RS (1998) Effect of dietary $n-3$ fatty acids on interleukin- 2 and interleukin- 2 receptor $\alpha$ expression in activated murine lymphocytes. Prostaglandins Leukot Essent Fatty Acids 58, 289-293.
37. Stulnig TM, Huber J, Leitinger N, et al. (2001) Polyunsaturated eicosapentaenoic acid displaces proteins from membrane rafts by altering raft lipid composition. $J$ Biol Chem 276, 37335-37340.

38. Ebinu JO, Stang SL, Teixeira C, et al. (2000) Ras GRP links T cell receptor signaling to Ras. Blood 95, 3199-3203.

39. Bi K \& Altman A (2001) Membrane lipid microdomains and the role of PKCq in $\mathrm{T}$ cell activation. Semin Immunol 13, 139-146.

40. Xavier R, Brennan T, Li Q, et al. (1998) Membrane compartmentalization is required for efficient $\mathrm{T}$ cell activation. Immunity 8, 723-732.

41. Gordge MP (1998) How cytotoxic is nitric oxide? Exp Nephrol 6, 12-16.

42. Boutard V, Fouquery B, Philippe C, et al. (1994) Fish oil supplementation and essential fatty acid deficiency reduce nitric oxide synthesis by rat macrophages. Kidney Int $\mathbf{4 6}$, 1200-1286.

43. Joe B \& Lokesh BR (1994) Role of capsaicin, curcumin and dietary $n-3$ fatty acids in lowering the generation of reactive oxygen species in rat peritoneal macrophages. Biochim Biophys Acta 1224, 255-263.

44. Renier G, Skamene E, de Sanctis J, et al. (1993) Dietary n-3 polyunsaturated fatty acids prevent the development of atherosclerotic lesions in mice: modulation of macrophage secretory activities. Arterioscler Thromb 13, 1515-1524.

45. Chaet MS, Garcia VF, Arya G, et al. (1994) Dietary fish oil enhances macrophage production of nitric oxide. J Surg Res 57, 65-68.

46. Hubbard NE, Chapkin RS \& Erickson KL (1994) Effect of dietary linseed oil on tumoricidal activity and eicosanoid production in murine macrophages. Lipids 29, 651-655.

47. Narayanan BA, Narayanan KN, Simi B, et al. (2003) Modulation of inducible nitric oxide synthase and related proinflammatory genes by the omega- 3 fatty acid docosahexaenoic acid in human colon cancer cells. Cancer Res 63, 972-979.

48. Aldridge C, Razzak A, Babcock TA, et al. (2008) LPS-stimulated RAW 264.7 macrophage inducible nitric oxide synthase (iNOS) and nitric oxide production is decreased by an omega-3 fatty acid lipid emulsion. J Surg Res 149, 296-302.

49. Ren J \& Chung SH (2007) Anti-inflammatory effect of ( $\gamma$-linolenic acid and its mode of action through the inhibition of nitric oxide production and inducible nitric oxide synthase gene expression via $\mathrm{NF}-\kappa \mathrm{B}$ and mitogen-activated protein kinase pathways. J Agr Food Chem 55, 5073-5080.

50. Jiang Q, Schwab IE, Courtemanche C, et al. (2000) $\gamma$-Tocopherol and its major metabolite, in contrast to $\alpha$-tocopherol, inhibit cyclooxygenase activity in macrophages and epithelial cells. Proc Natl Acad Sci U S A 97, 11494-11499.

51. Allen RC (1994) Role of oxygen in phagocyte microbicidal action. Environ Health Perspect 102, Suppl. 10, 201-208.

52. Schnyder J \& Baggiolini M (1978) Secretion of lysosomal hydrolases by stimulated and nonstimulated macrophages. $J$ Exp Med 148, 435-450. 